\title{
Studies on autoantibodies to poly (adenosine diphosphate-ribose) in SLE and other autoimmune diseases
}

\author{
W. J. W. MORROW ${ }^{1}$ D. A. ISENBERG ${ }^{2} H . F . P_{A R R Y^{2}}$ L. SHEN $^{1}$ \\ E. E. OKOLIE ${ }^{3}$ F. FARZANEH ${ }^{3}$ S. SHALL AND M. L. SNAITH ${ }^{2}$ \\ From the ${ }^{1}$ Department of Immunology, Middlesex Hospital Medical School, London; the ${ }^{2}$ Departments of \\ Haematology and Rheumatology, University College Hospital, London; and the ${ }^{3}$ Biochemistry Laboratory, \\ School of Biological Sciences, University of Sussex, Brighton
}

SUMMARY Sera from 41 patients with systemic lupus erythematosus (SLE), 87 controls with various diseases, and 30 normal subjects were examined for poly (adenosine diphosphate-ribose) and ds DNA binding. Elevated levels of poly (ADP-ribose) binding were found in $73 \%$ of the SLE patients compared with $58 \%$ who had raised ds DNA binding. In a further study of 160 sera from 27 patients with SLE, levels of antipoly (ADP-ribose) antibodies were shown to correlate with clinical activity better than either anti-ds DNA or ss DNA antibodies.

Poly (ADP-ribose) is a nuclear polymer formed from nicotinamide adenine dinucleotide (NAD) by action of the chromatin bound enzyme, poly (ADP-ribose) polymerase, with the loss of the nicotinamide moiety. Its structure and physiochemical characteristics have been reviewed, ${ }^{12}$ though its precise function within the nucleus remains unknown.

Antibodies to a variety of nuclear antigens including double-stranded (ds) DNA, single-stranded (ss) DNA, polyribonucleotides, ribosomes, ds and ss RNA, both synthetic and naturally occurring, have been reported in systemic lupus erythematosus (SLE). ${ }^{3-8}$ In particular, ds DNA antibodies are important in the diagnosis of the disease. ${ }^{9}$

Recently the occurrence of antibodies to poly (ADP-ribose) has been reported. ${ }^{10}$ Okolie and Shall ${ }^{11}$ have demonstrated in a preliminary study that these antibodies show specificity for SLE. However, the number of patients with other diseases examined by them was comparatively small. Therefore one of the aims of this investigation was to examine a larger group of patients with SLE and related diseases in order to compare the specificity of autoantibodies to poly (ADP-ribose) with ds DNA. The latter were tested with a widely used, commercially available kit.

It has also been reported that antibodies to nuclear

Accepted for publication 13 July 1981.

Correspondence to Dr W. J. W. Morrow, Department of Immunology, Middlesex Hospital Medical School, Arthur Stanley House, 40-50 Tottenham Street, London W1P 9PG.

*Present address, National Institute of Medical Research, Lagos, Nigeria. antigens, in particular antibodies to ds DNA, are useful in the management of SLE patients. ${ }^{11-13}$ Antibodies to ss DNA may also reflect disease activity. ${ }^{14}$ This study correlates levels of antibodies to poly (ADP-ribose) and DNA with clinical activity in patients with SLE. The relationship of levels of these antibodies to those of ds DNA and ss DNA has also been explored.

\section{Patients and methods}

In the first part of the study sera from 41 patients with 4 or more of the American Rheumatism Association's criteria for the classification of systemic lupus

Table 1 Correlation coefficients on transformed values

\begin{tabular}{|c|c|c|c|c|}
\hline \multirow[t]{2}{*}{ Patient } & \multicolumn{2}{|c|}{$\begin{array}{l}\% \text { Poly (ADP-ribose) binding } \\
\text { and } \% \text { ds DNA binding }\end{array}$} & \multicolumn{2}{|c|}{$\begin{array}{l}\% \text { Poly (ADP-ribose) binding } \\
\text { and \% ss DNA binding }\end{array}$} \\
\hline & $\begin{array}{l}\text { No. of } \\
\text { readings }\end{array}$ & $\begin{array}{l}\text { Correlation } \\
\text { coefficient }\end{array}$ & $\begin{array}{l}\text { No. of } \\
\text { readings }\end{array}$ & $\begin{array}{l}\text { Correlation } \\
\text { coefficient }\end{array}$ \\
\hline 1 & 5 & -0.61 & 5 & $0.99^{* * *}$ \\
\hline 2 & 4 & 0.83 & 4 & $0 \cdot 80$ \\
\hline 3 & 6 & $0 \cdot 14$ & 5 & 0.43 \\
\hline 4 & 5 & 0.76 & 5 & $0.85^{*}$ \\
\hline 5 & 5 & 0.78 & 5 & $0 \cdot 54$ \\
\hline 6 & 4 & 0.79 & 4 & -0.08 \\
\hline 7 & 6 & 0.49 & 6 & 0.70 \\
\hline 8 & 6 & -0.57 & 6 & -0.50 \\
\hline 9 & 11 & $0 \cdot 79^{* *}$ & 10 & $0.93^{* * *}$ \\
\hline 10 & 14 & $0 \cdot 13$ & 14 & 0.45 \\
\hline 11 & 14 & $0.81^{* * *}$ & 14 & $0.72^{* *}$ \\
\hline Total & 80 & & 78 & \\
\hline
\end{tabular}

${ }^{*} p \gtrless 0 \cdot 05 ;{ }^{* *} p \gtrless 0 \cdot 01 ;{ }^{* * *} p \gtrless 0 \cdot 001$. 


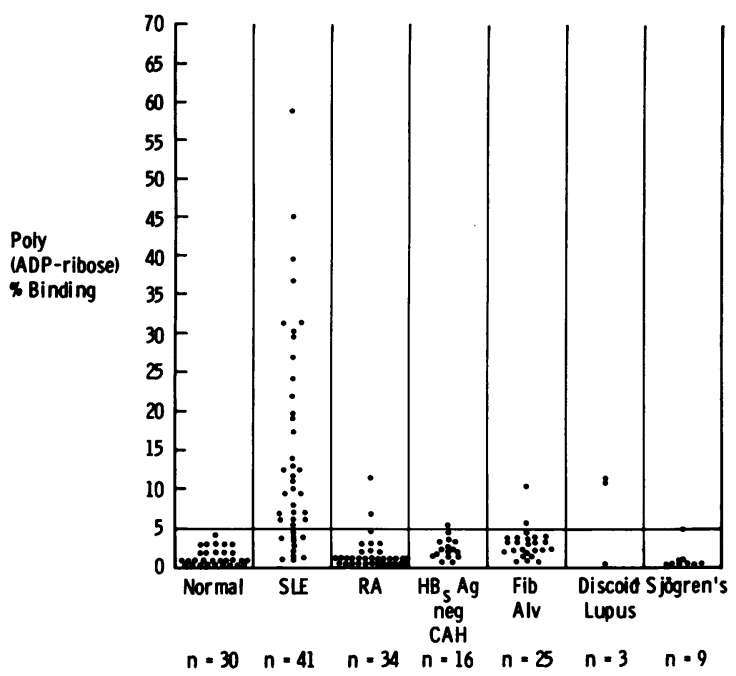

Fig. 1 Distribution of poly (ADP-ribose) binding (\%) of normal sera, SLE and non-lupus disease controls. Normal range up to $5 \%$.

erythematosus ${ }^{12}$ were examined. In addition the sera from 34 patients with definite rheumatoid arthritis (diagnosed by the criteria of Ropes et al. ${ }^{13}$ ), 25 patients with fibrosing alveolitis (diagnosed by the criteria of Turner-Warwick ${ }^{14}$ ), 16 patients with hepatitis B surface antigen-negative chronic hepatitis (diagnosed by the clinical and serological criteria of Sherlock ${ }^{15}$ ), 9 patients with Sjögren's syndrome (diagnosed by the criteria of Bloch et al. ${ }^{16}$ ), and 3 patients with discoid lupus were also examined. Thirty healthy volunteers were venesected to establish a normal range for the antipoly (ADP-ribose) binding test. Their ages ranged from 22 to 65 to cover the full range of the patients studied.

In the second part of the study a total of 106 sera from 27 patients with SLE were analysed. Serum samples were collected and stored at $-20^{\circ} \mathrm{C}$ until required.

\section{CLINICAL ACTIVITY}

Patients were classified into 3 clinical groups, having inactive, moderately active, or severely active disease. Moderate activity was judged to be present if one or two of the following were in evidence: pleuritis, pericarditis, arthralgia, myalgia, vasculitis, cerebral involvement, or renal involvement. Patients were considered to have severely active disease in the presence of 3 or more of these features. Patients were considered to be 'inactive' if they had no, or minimal evidence of any subjective or objective activity-for example, Ritchie artıcular index less than 3 or pleuritic pain on only 1 or 2 days in the previous month or proteinuria between 0.05 and $0.1 \mathrm{~g} / 24$ hours in a normotensive patient with otherwise completely normal renal function tests. Clinical assessments were made without prior knowledge of the poly (ADP-ribose) or DNA binding measurements for the same day.

POLY (ADP-RIBOSE) BINDING ACTIVITY

Poly (ADP-ribose) was prepared by the method of Okolie and Shall ${ }^{11}$ from tritiated $\left({ }^{3} \mathrm{H}\right)$ NAD with calf thymus poly (ADP-ribose) polymerase. The resulting polymer was purified to remove nuclear proteins and nucleic acids. The average chain length was 20 ADP-ribose units. Specific poly (ADP-ribose) binding activity was assayed according to the Farr technique. ${ }^{17} 10 \mu \mathrm{l}$ poly (ADP-ribose) containing 5000 counts per minute was incubated with $40 \mu$ l heat inactivated test serum and $155 \mu$ l potassium-free 10 $\mathrm{mM}$ phosphate buffer containing $140 \mathrm{mM}$ sodium chloride. The reaction mixture was incubated at $37^{\circ} \mathrm{C}$ for 1 hour with gentle shaking and then left for 48 hours at $4^{\circ} \mathrm{C}$ to reach equilibrium. Antibody bound ${ }^{3} \mathrm{H}$ poly (ADP-ribose) was then precipitated by the addition of an equal volume $(200 \mu \mathrm{l})$ of cold saturated ammonium sulphate. After incubation at $4^{\circ} \mathrm{C}$ the precipitates were washed twice with ammonium sulphate; dissolved in $0.45 \mu$ l distilled water, and

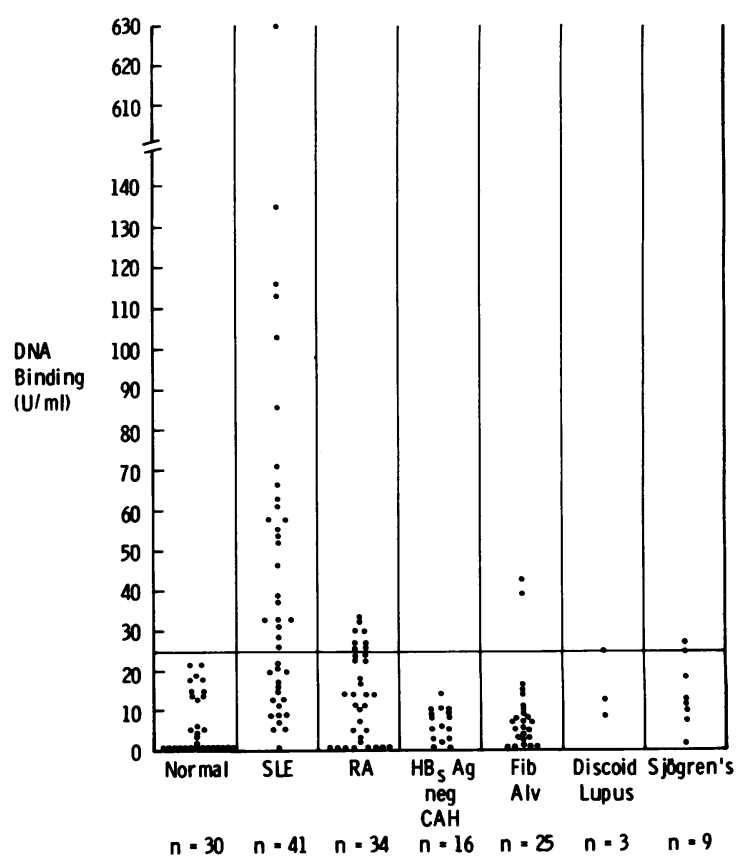

Fig. 2 Distribution of ds DNA binding (U/ml) of normal serum, SLE and non-lupus disease controls. Normal range up to $25 \mathrm{U} / \mathrm{ml}$. 


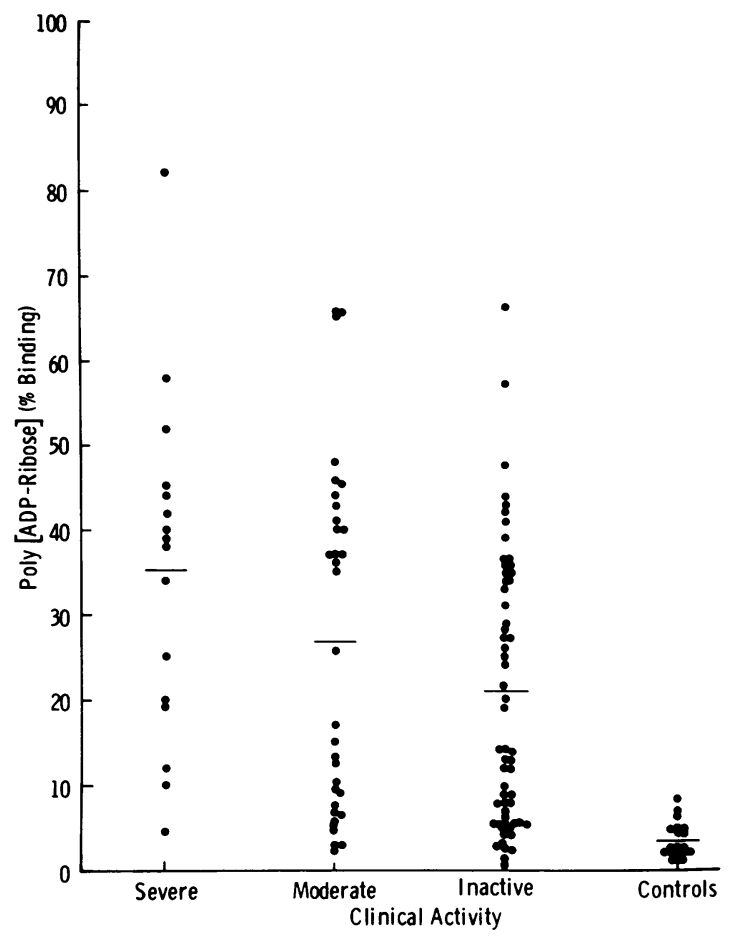

Fig. 3 Poly (ADP-ribose) binding (\%) grouped according to clinical activity. Normal levels of poly (ADP-ribose) binding $<9 \cdot 2 \%$.

mixed with $3.0 \mathrm{ml}$ scintillation fluid (Picofluor 15, Packard Instruments, Berks), and the radioactivity was measured in a Packard liquid scintillation counter. Results were expressed as percentages of the original radioactivity introduced in each tube. Estimations were carried out in triplicate on every specimen of sera. The results given for this test are thus a mean of the 3 estimations.

DNA BINDING ACTIVITY

In the first part of the study DNA binding was measured with anti-DNA assay kits obtained from the Radiochemical Centre, Amersham, England. This is a standardised assay for measuring antibodies to ds DNA in serum, again by a modified Farr ${ }^{17}$ procedure. The kit contains all the reagents and instructions required for the assay. The ${ }^{125}$ I deoxyuridine-DNA was incubated with heat-inactivated sera and the binding activity of each serum compared with those of 4 known SLE serum standards provided in the kit. The results were expressed in arbitrary units $/ \mathrm{ml}$ of serum. ${ }^{18}$

For the second part of the study a commercial preparation of Escherichia coli DNA, internally labelled with tritium (specific activity $14 \cdot 3 \mu \mathrm{Ci} / \mathrm{A}_{260}$ unit) was obtained from Miles Laboratories, Slough, England. This had been sonicated to give fragments with an average molecular weight of 100000 Daltons. It was virtually all double-stranded material of even chain length, as determined by digestion with Exonuclease III. RNA was removed by treatment with RNase. A solution of $1 \mu \mathrm{g}$ DNA ml${ }^{-1}$ was made in borate buffered saline (BBS) $\mathrm{pH} 8 \cdot 3$, containing $1 \%(\mathrm{w} / \mathrm{v})$ bovine serum albumin. Aliquots $(10 \mu \mathrm{l})$ of this were mixed with $10 \mu \mathrm{l}$ of normal or patient's serum diluted $1: 10$ with phosphate buffered saline (PBS). The resulting mixture was incubated in Microfuge tubes (Beckman Instruments, High Wycombe, Bucks) for 1 hour at $37^{\circ} \mathrm{C}$ and overnight at $4^{\circ} \mathrm{C}$. Saturated ammonium sulphate $(20 \mu \mathrm{l})$ was added and the tube contents mixed immediately. The resultant precipitate was spun down in a Beckman Microfuge and the pellet dissolved in $0.5 \mathrm{~N} \mathrm{NaOH}$. This was transferred to a scintillation vial and mixed with $3 \mathrm{ml}$ Picofluor 15 (Packard Instruments, Berks). Samples were counted in a Packard scintillation counter.

The assay for single stranded anti-DNA antibodies was performed identically with DNA which had been treated for 10 minutes at $100^{\circ} \mathrm{C}$ and placed immediately on ice.

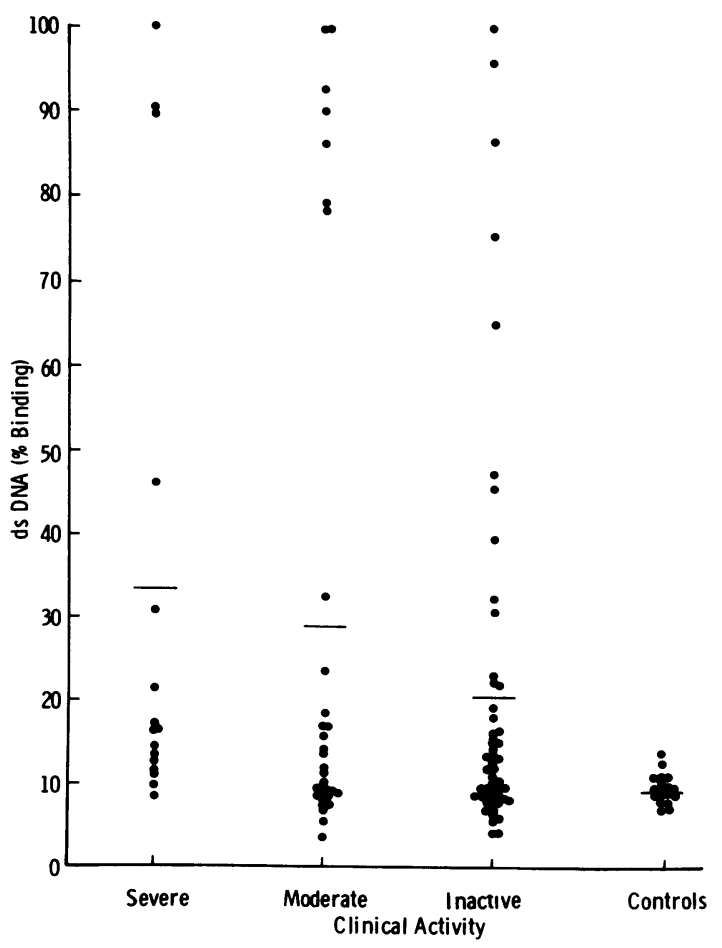

Fig. 4 ds DNA binding grouped according to clinical activity. Normal levels of ds DNA binding $<14 \cdot 6 \%$. 


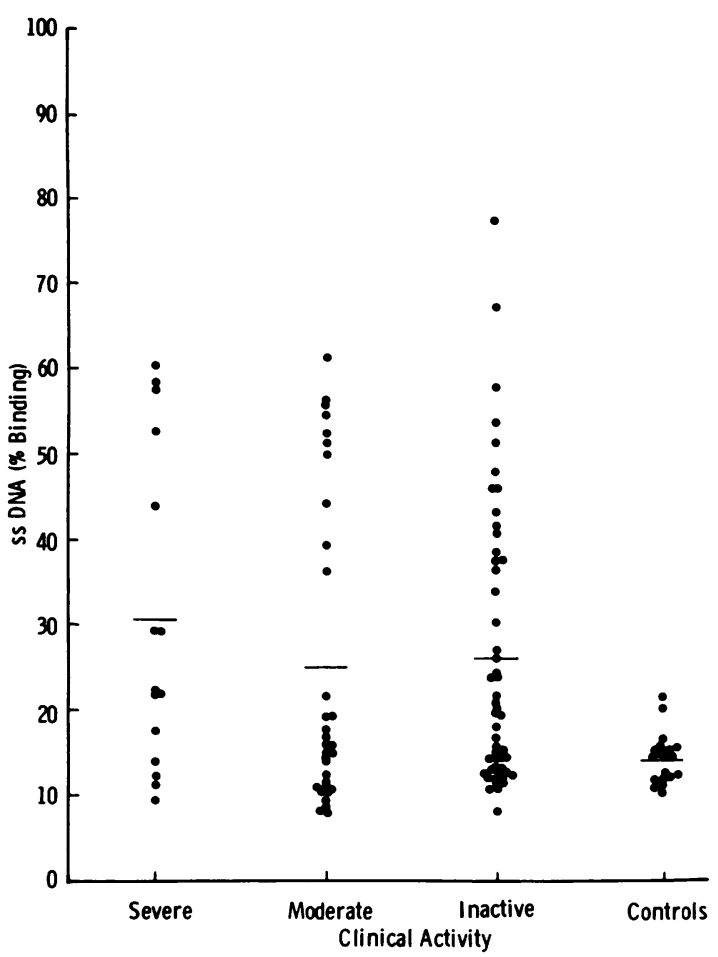

Fig. 5 ss DNA binding grouped according to clinical activity. Normal levels of ss $D N A<22 \cdot 8 \%$.

Results were expressed as a percentage of radioactivity initially introduced into each tube.

In both tests with the commercial preparation of $E$. coli DNA upper limits of normal were established as a mean value plus 3 standard deviations of 20 normal controls.

\section{Results}

\section{SPECIFICITY TESTING}

Samples were considered to have elevated binding of poly (ADP-ribose) antibodies if they exceeded $5 \%$ of the bound radioactivity. This figure was slightly greater than the mean $(1.6 \%)$ plus 3 standard deviations $(\mathrm{SD}=1.1 \%$; mean $+3 \mathrm{SD}=4.9 \%)$ of the sera from the first group of 30 normal subjects.

DNA binding was considered to be elevated, when it was above 25 units $/ \mathrm{ml}$, as recommended by the manufacturers (Amersham Kit).

The results of poly (ADP-ribose) binding in the different groups are shown in Fig. 1 and those for the DNA binding in Fig. 2. Increased binding activity for poly (ADP-ribose) was found in $73 \%$ of the SLE patients compared with $58 \%$ who showed elevated ds DNA binding.
RELATIONSHIP OF ANTIBODY LEVELS TO

DISEASE ACTIVITY

A covariance analysis of antipoly (ADP-ribose) binding with disease activity (after arcsine transformation of the percentage values of antipoly (ADP-ribose) antibodies) was carried out on all 27 patients. The scale of disease activity was assumed to be linear. A highly significant trend was found to exist between the antipoly (ADP-ribose) values and disease activity: regression coefficient $b=4 \cdot 1147$ with standard error $=1.30, p<0.001$ (Fig. 3 ). High levels $(>30 \%$ binding) of antipoly (ADP-ribose) antibodies were found in 4 patients whose disease was clinically quiescent. In a further 3 patients high levels of binding activity were found to precede clinical relapse.

Low levels ( $<20 \%$ binding) were detected in one patient during an acute exacerbation of her disease. There was no significant relationship between types of organ involvement and levels of poly (ADPribose) binding; however, a larger sample may reveal such associations.

There was no significant statistical correlation between levels of either ds DNA or ss DNA and clinical activity, significance being taken at the $5 \%$ level (Figs. 4 and 5).

Comparison between the levels of antigen binding in the various clinical states was also made by using Student's $t$ test on arcsine transformed values. This analysis does not assume that a linear relationship exists between the clinical states. This revealed that poly (ADP-ribose) binding levels were significantly different $(0.001<p<0.01)$ between the severe and the inactive disease states (Fig. 3), though not between the moderate and the other groups. ds DNA binding levels (Fig. 4) in the inactive and severe clinical groups were also significantly different $(0.01<p<0.05)$, though this degree of significance is not as high as that obtained with the poly (ADPribose) binding. No significantly different levels were found between ss DNA binding in the various clinical states with the exception of the difference between the controls and the inactive group (Fig. 5). There was a significant difference between levels of binding of both poly (ADP-ribose) and ds DNA in the control and inactive groups $(0 \cdot 01<\mathrm{p}<0.05)$.

RELATIONSHIP BETWEEN ANTIPOLY (ADPRIBOSE), ANTI-DS DNA AND ANTI-SS DNA

The correlation coefficients were calculated for each patient separately. Only 11 patients with at least 4 pairs of readings were included in the analysis. Correlation coefficients between poly (ADP-ribose) binding and ds DNA binding in individual patients (Table 1) ranged from -0.6 to 0.83 with only 2 values showing significance $(p<0 \cdot 05)$. Correlation coefficients between poly (ADP-ribose) binding and ss 


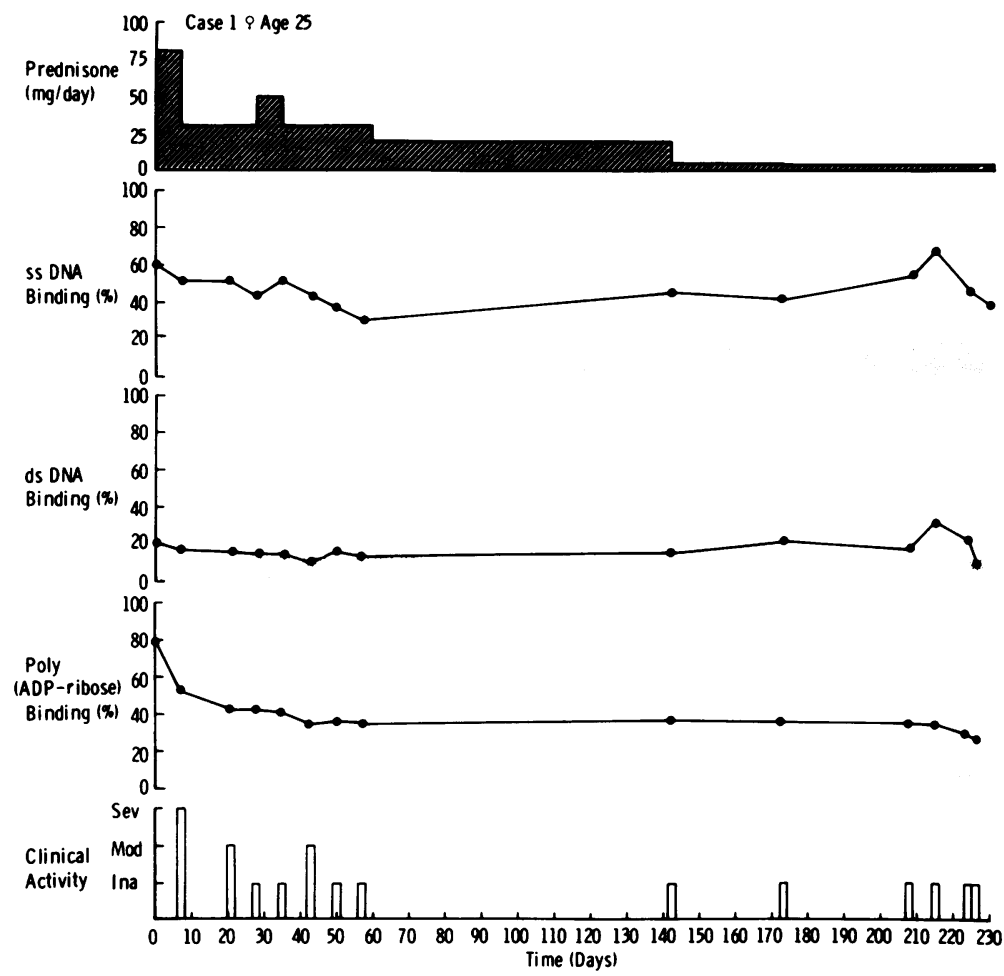

Fig. 6 Longitudinal studies on case 1: shaded areas denote normal ranges.

DNA binding (Table 1) ranged from -0.05 to 0.99 with 4 values showing significance $(p<0 \cdot 05)$. This lack of significance may be a consequence of small sample size. The overall correlation coefficients (r) between poly (ADP-ribose), ds DNA, and ss DNA calculated from all sera tested were $0.45(\mathrm{p}<0.001$, $\mathrm{n}=106)$ and $0.58(\mathrm{p}<0.001, \mathrm{n}=102)$ respectively. These findings should be treated with some caution, however, as it is possible that the differing number of samples taken from individual patients may bias the data.

Thirty abnormal poly (ADP-ribose) binding results were recorded on sera which had normal ds DNA binding, whereas no sera had abnormal ds DNA binding when poly (ADP-ribose) binding was normal. Similarly there were 29 abnormal poly (ADPribose) binding results in the presence of normal ss DNA binding. Conversely, only one ss DNA binding result fell outside the normal range when the corresponding poly (ADP-ribose) binding was normal.

LONGITUDINAL STUDIES ON SELECTED CASES Case 1 (Fig. 6). This 25-year-old female with homozygous C2 deficiency had a history of immune thrombocytopenia 7 years prior to this study, successfully treated with steroids. Since that time she had suffered intermittently from arthralgia. At the begin- ning of this study she was admitted with acute exacerbation of her SLE, with unexplained pyrexia, vomiting, and diarrhoea, hypotension, maculopapular rash, confusion, and arthralgia. Haemoglobin was $9.3 \mathrm{~g} / \mathrm{dl}$, platelets were $105 \times 10^{9} / 1$, leucocytes $2.7 \times 10^{9} / 1$. She also had a classical lupus anticoagulant.

Initial levels of antipoly (ADP-ribose) antibodies were very high ( $82 \%$ bound). She was treated at first with prednisolone, $80 \mathrm{mg} /$ day, and over the next 2 weeks her condition improved, this change being reflected in the fall of antibodies. Levels of antibodies to ds DNA and ss DNA showed a less close relationship. Her subsequent course has been a steady improvement, and at the end of the period of study she was in complete remission.

Case 2 (Fig. 7). This 27-year-old female patient first presented 4 years before the commencement of this study with polyarthralgia, rash, and pleuropericarditis. As can be seen from Fig. 7 she was in remission at the beginning of the study but was subsequently admitted to hospital with an acute exacerbation. At this time she had polyarthralgia, pleural and pericardial effusions, myocarditis, and involvement of her gastrointestinal tract and central nervous system (acute psychotic episode). She was initially treated with $1 \mathrm{~g}$ boluses of 


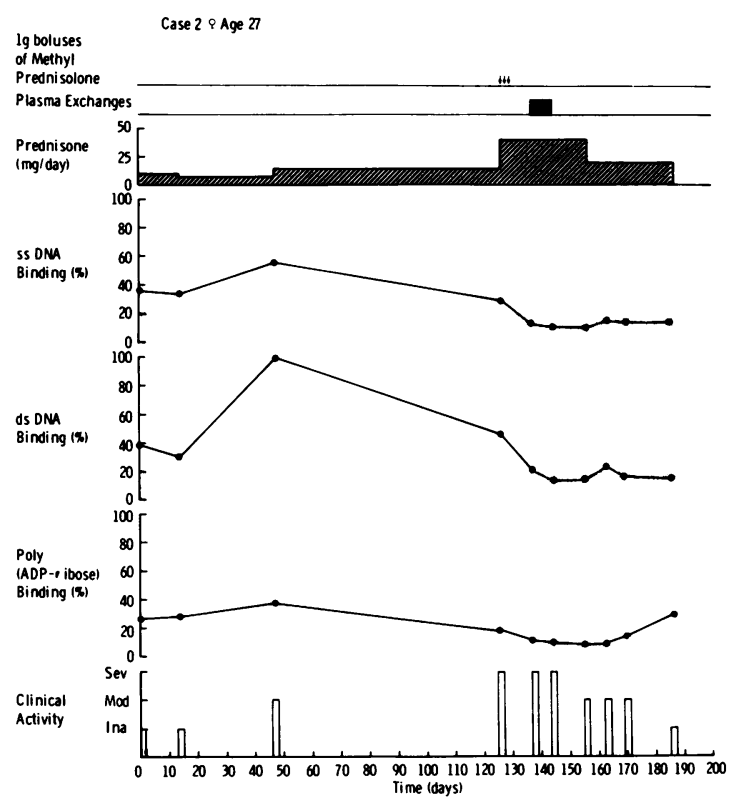

Fig. 7 Longitudinal studies on case 2: shaded areas denote normal ranges.

methylprednisolone, which did not result in clinical improvement but lowered the levels of anti-DNA and anti-poly (ADP-ribose) antibodies. She was then treated with a series of plasma exchanges, which resulted in clinical improvement.

\section{Discussion}

It is unlikely that a disease as variable as SLE could have a single diagnostic test. While antibodies to ds DNA are largely confined to SLE ${ }^{1920}$ raised levels have also been detected in the serum of patients with discoid lupus erythematosus, ${ }^{21}$ rheumatoid arthritis and fibrosing alveolitis, ${ }^{11}$ chronic active hepatitis, primary biliary cirrhosis, alcoholic cirrhosis, and portal vein obstruction. ${ }^{22}$

However, antibodies to ds DNA have until now been the best single test available in diagnosing SLE. The Amersham kit is a widely available test for DNA autoantibodies. Its antigenic component is claimed to be free of ss DNA,${ }^{23}$ which may contaminate ds DNA preparations and cause lack of specificity. We therefore chose this assay to compare with levels of poly (ADP-ribose) binding.

Raised levels of poly (ADP-ribose) binding were found more frequently than raised levels of DNA binding in SLE. In rheumatoid arthritis, which is one of the most common differential diagnoses from SLE in its early stages, the number of false positives was lower with the poly (ADP-ribose) binding test.
Five other non-SLE patients had raised DNA binding levels compared with 6 ( 2 of whom had discoid LE) who had raised poly (ADP-ribose) binding. We are aware that there are difficulties in making comparisons between even apparently similar assays. It is possible that the upper limit of normal for the Amersham test may be set artificially high by the manufacturer to exclude false positives arising from suboptimal conditions. In a future study it would be useful to standardise the units of measurement in both assays. Nevertheless poly (ADP-ribose) binding activity would appear to be as good as, and in certain respects better than, DNA binding for the diagnosis of SLE.

Assessment of disease activity in SLE is difficult. Some have opted for a complicated point scoring system, ${ }^{24}$ but in common with other groups ${ }^{25}{ }^{26}$ we have used a simpler method which reflects our own experience that patients who are very ill usually have involvement of several organs or systems. Because of the problem of adequate clinical assessment, there is a need for sensitive, objective tests to reflect disease activity.

Serial estimations of ds DNA autoantibodies as a means of assessment of disease activity in SLE have been found to be useful. ${ }^{27}$ In contrast antibodies to ss DNA show less specificity for SLE, although they may be useful in monitoring disease activity, and levels may be raised when ds DNA binding is normal. ${ }^{28}$

Our results show a good overall relationship between levels of antibodies to poly (ADP-ribose) and clinical activity, suggesting the usefulness of the test as a therapeutic guide. However, we did not find a statistically significant association between antibodies to ds DNA, ss DNA, and clinical activity. This latter statement is in keeping with observations of some workers who found that fluctuations in antiDNA antibody levels did not always correlate with disease activity. ${ }^{29}{ }^{30}$ High levels of all types of antibody measured were found in some patients with clinically quiescent disease, this trend being more marked with antibodies to DNA than to poly (ADPribose). We could demonstrate no association between levels of antibody to poly (ADP-ribose), ds DNA, and ss DNA, and pattern of organ involvement, although our numbers may be too small to show a trend. Overall our results showed a statistically significant correlation between levels of antipoly (ADP-ribose) antibodies and anti-ds DNA antibodies; this was not as high as that reported by Okolie and Shall, ${ }^{11}$ though with some individuals the correlation was close. This may reflect the different preparations of ds DNA used in the 2 assays or it is possible that a trend could become clearer on a larger sample. A significant overall correlation was 
observed between antipoly (ADP-ribose) and anti-ss DNA antibodies.

The measurement of antipoly (ADP-ribose) antibodies has certain advantages over that of anti-ds DNA. The reproducibility is good, ${ }^{11}$ it is a simple assay to perform, and the antigen is small and highly defined. In its preparation the use of DNase and RNase renders it free of nucleic acids, and a phenol extraction removes nuclear proteins, including histones. This is in contrast to ds DNA, where contamination with ss DNA of varying molecular weights may produce differing results. ${ }^{31}{ }^{32}$ In all 3 antibody assays low levels of binding were found in normal sera, though poly (ADP-ribose) binding was much lower than DNA binding.

In conclusion it would seem reasonable to suggest that the measurement of poly (ADP-ribose) autoantibodies may provide a useful specific diagnostic test for SLE. While it is unlikely that any single measurement will be an adequate guide in the management of SLE, poly (ADP-ribose) binding has potential as an addition to existing methods of assessing disease activity.

The authors thank Professor I. M. Roitt for helpful criticism of the manuscript, Pippa Skevington of the MRC statistics unit for advice on the data analysis, and Jane De Stoop for typing the text.

Our thanks also to the following who helped us to collect the sera tested: Dr Ian Barrison, Jean Bond, Dr Caroline Dunne, Dr Pat Haslam, Dr Eva Lester, Dr V. Martin, Dr A. Pringle, Dr Jean Reeve, Ursula Shipton, Dr H.C. Thomas, Professor Margaret Turner-Warwick, and Dr A. G. White.

W.J.W.M., H.F.P., and D.A.I. were supported by fellowships from the Sir Jules Thorn Foundation; E.E.O., F.F., and S.S. were funded by the Cancer Research Campaign, the Medical Research Council, and the Science Research Council.

\section{References}

' Sugimura T. Poly (adenosine diphosphate-ribose). Progr Nucleic Acid Res Molec Biol 1973; 12: 125-51.

${ }^{2}$ Hayaishi O, Ueda K. Poly (ADP-ribose) and ADP ribosylation of proteins. Ann Rev Biochem 1977; 46: 59-116.

${ }^{3}$ Steinberg A D, Baron S, Talal N. The pathogenesis of autoimmunity in New Zealand mice 1. Induction of antinucleic acid antibodies by polyinosinic polycytidylic acid. Proc Nat Acad Sci (USA) 1969; 63: 1102-7.

4 Schur P H, Monroe M. Antibodies to ribonucleic acid in systemic lupus erythematosus. Proc Nat Acad Sci (USA) 1969; 63: 1108-1112.

${ }^{5}$ Koffler D, Carr R, Agnello V, Thorburn R, Kunkel H G. Antibodies to polynucleotides in human sera: Antigen specificity and relation to disease. J Exp Med 1971; 134: 294-312.

6 Talal N, Steinberg A D, Daley G G. Inhibition of antibodies binding polyinosinic polycyticdylic acid in human and mouse lupus sera by viral and synthetic ribonucleic acids. $J$ Clin Invest 1971; 50: 1248-52.

' Schur P H, Stollar D, Steinberg A D, Talal N. Incidence of antibodies to double-stranded RNA in systemic lupus erythemnatosus and related diseases. Arthritis Rheum 1971; 14: 342-7.

${ }^{8}$ Eilat D, Steinberg A D, Schechter A N. The reaction of SLE antibodies with native, single stranded RNA: radioassay and binding specificities. J Immunol 1971; 120: 550-7.

9 Reichlin M, Mattioli M. Antigens and antibodies characteristic of systemic lupus erythematosus. Bull Rheum Dis 1974; 24: 756-60.
${ }^{10}$ Kanai Y, Kawaminami Y, Miwa M, Matsushima T, Sugimura T. Naturally occurring antibodies to poly (ADP-ribose) in patients with systemic lupus erythematosus. Nature 1977; 265: 175-7.

${ }^{11}$ Okolie E E, Shall S. The significance of antibodies to poly (ADPribose) in patients with systemic lupus erythematosus. Clin Exp Immunol 1979; 36: 151-64.

12 Cohen A S, Reynolds W E, Franklin E C, et al. Preliminary criteria for the classification of systemic lupus erythematosus. Bull Rheum Dis 1971; 21: 643-8.

${ }^{13}$ Ropes M W, Bennett G A, Cobb S, Jacob R, Jessar R A. Revision of diagnostic criteria for rheumatoid arthritis. Bull Rheum Dis 1958; 9: 175-6.

${ }_{14}$ Turner-Warwick M. Cryptogenic fibrosing alveolitis. Br J Hosp Med 1972; 7: 697-704.

${ }^{15}$ Sherlock S. Chronic hepatitis. Gut 1979; 15: 581-97.

${ }^{16}$ Bloch K J, Buchanan W W, Wahl M J, Bunim J J. Sjögren's syndrome. A clinical, pathological and serological study of sixty two cases. Medicine 1965; 44: 187-231.

${ }_{17}$ Farr R. A quantitative immunochemical measure of the primary interaction between I*-BSA and antibody.J Infect Dis 1958; 103: 239-62.

${ }^{18}$ Holian J, Griffiths I D, Glass D N, Maini R N, Scott J T. Human anti-DNA antibody: reference standards for diagnosis and arrangement of systemic lupus erythematosus. Ann Rheum Dis $1975 ; 34: 438-43$.

19 Pincus T, Schur P H, Rose J A, Deker J L, Talal N. Measurement of serum DNA binding activity in SLE. $N$ Engl J Med 1969; 281: 701-5.

${ }^{20}$ Hughes G R V, Cohen S A, Christian C L. Anti-DNA activity in systemic lupus erythematosus. Ann Rheum Dis 1971;30: 359-64.

${ }^{21}$ Lightfoot R W. Significance of persistent serological abnormalities in systemic lupus erythematosus (abstract). Arthritis Rheum 1972; 15: 445.

${ }^{22}$ Jain S, Markham R, Thomas M C, Sherlock S. Double-stranded DNA binding capacity of serum in acute and chronic liver disease. Clin Exp Immunol 1976; 26: 35-41.

${ }^{23}$ Davis P, Russell A S, Percy J S. A comparative study of techniques for the detection of antibodies to native DNA. Am J Clin Pathol 1977; 67: 374-8.

24 Cameron J S, Lessof M H, Ogg C S, Williams B D, Williams D G. Disease activity in the nephritis of systemic lupus erythematosus in reaction to serum complement concentrations: DNA-binding capacity and precipitating anti-DNA antibody. Clin Exp Immunol 1976; 25: 418-27.

${ }^{25}$ Rothfield N F, Pace N. Relation of positive LE cell preparations to activity of lupus erythematosus and corticosteroid therapy. $N$ Engl J Med 1962; 266: 535-8.

${ }^{26}$ Zein N,. Ganzua C, Kushner I. Significance of serum C-reactive protein elevation in patients with systemic lupus erythematosus. Arthritis Rheum 1979; 22: 7-12.

${ }^{27}$ Lightfoot R W, Redecha P B, Levesanos N. Longitudinal studies of anti-DNA antibody levels in SLE. Scand J Rheumatol 1975; 11 suppl: 52 .

${ }^{28}$ Lange A. Evaluation of the simultaneous estimation of anti-ds DNA and anti-ss DNA antibodies for clinical purposes. Clin Exp Immunol 1978; 31: 472-81.

${ }^{29}$ Edmonds J P, Johnson G D, Ansell B M, Holborrow J. The value of tests for antibodies to DNA in monitoring the clinical course of SLE: a long-term study using the Farr test and the DNA counter immunoelectrophoretic method. Clin Exp Immunol 1975; 22: 9-15.

${ }^{30}$ Davis P, Percy J S, Russell A S. Correlation between levels of DNA-antibodies and clinical disease activity in SLE. Ann Rheum Dis 1977; 36: 157-9.

31 Aarden L A, Lakmaker R, Feltkamp T E W. Immunology of DNA II: The effect of size and structure of the antigen on the Farr assay. J Immunol Methods 1976; 10: 39-48.

${ }^{32}$ Feltkamp T E W. The significance and determination of antiDNA and DNA/anti-DNA complexes. Scand J Rheumatol 1975; 11 suppl: 1. 